\title{
Influence of topical acidulated phosphate fluoride on surface roughness of human enamel and different restorative materials
}

\author{
Influência da aplicação tópica de flúor fosfato acidulado sobre \\ a rugosidade superficial do esmalte humano e de diferentes \\ materiais restauradores
}

\begin{abstract}
Purpose: The aim of this study was to assess the influence of topical acidulated phosphate fluoride on the surface roughness of both human enamel and different restorative materials. Methods: Resin-modified glass ionomer (Vitremer - V), microhybrid composite resin with fluoride (Tetric Ceram - T), and nanofiller composite resin without fluoride $(Z 350-Z)$ were evaluated. Acidulated phosphate fluoride (APF, 1.23\%) was applied to half of the specimens (groups VF, TF, ZF and EF). Ten intact human third molars were used to obtain enamel specimens (E). Six experimental groups $(n=10)$ and two control groups $(n=10)$ were formed. The mean surface roughness $(\mathrm{Ra})$ of both the restorative materials and enamel, with and without fluoride, was evaluated with a profilometer. Data were analyzed with an ANOVA, Tukey's test, Student's t-test, and Dunn-Bonferroni test at the 5\% significance level.

Results: The mean values of surface roughness, in micrometers, were as follows: $Z=0.60$; $\mathrm{TF}=1.00 ; \mathrm{ZF}=1.05 ; \mathrm{VF}=1.18 ; \mathrm{T}=2.10 ; \mathrm{V}=2.70 ; \mathrm{E}=16.99$; and $\mathrm{EF}=21.19$. Both $\mathrm{E}$ and $\mathrm{EF}$ presented significantly higher surface roughness than the other experimental groups.

Conclusion: It was concluded that APF increased the surface roughness of enamel and decreased the surface roughness of both resin-modified glass-ionomer cement and microhybrid composite resin with fluoride. The surface roughness of the nanofiller composite resin was not modified by APF.
\end{abstract}

Key words: Surface roughness; composite resin; resin-modified glass ionomer cement; dental enamel; fluoride

\section{Resumo}

Objetivo: Este estudo avaliou a influência da aplicação tópica de flúor fosfato acidulado sobre a rugosidade do esmalte e de diferentes materiais restauradores.

Metodologia: Amostras de cimento de ionômero de vidro modificado por resina (Vitremer - V), resina composta microhíbrida com flúor (Tetric Ceram - T) e resina nanopartículada sem flúor em sua composição (Z350 - Z) foram confeccionadas. Metade das amostras recebeu aplicação tópica de flúor fosfato acidulado a 1,23\% (FFA) (grupos VF, TF, ZF e EF) e a outra metade não, totalizando 6 grupos experimentais $(n=10)$. Dez terceiros molares humanos hígidos foram utilizados para confecção de amostras de esmalte $(E)$, constituindo os grupos controles $(n=10)$. A rugosidade média superficial ( $R a)$ dos materiais restauradores e do esmalte, com e sem flúor, foi analisada pelo rugosímetro. Os dados foram submetidos à análise de variância, testes de Tukey, t-Student e de Dunn-Bonferroni a 5\% de significância.

Resultados: Os valores médios de rugosidade, em micrometros, foram: $Z=0,60 ; T F=1,00$; $Z F=1,05 ; V F=1,18 ; T=2,10 ; V=2,70 ; E=16,99$ e $E F=21,19 . E$ e $E F$ apresentaram Ra significativamente superior aos grupos experimentais.

Conclusão: Concluiu-se que o FFA aumentou a rugosidade do esmalte, diminuiu a do cimento de ionômero de vidro e da resina microhíbrida com flúor e não alterou a rugosidade da resina nanoparticulada sem flúor.

Palavras-chave: Rugosidade superficial; resina composta; cimento de ionômero de vidro modificado por resina; esmalte dental; flúor

\author{
Ana Carolina Botta a \\ Fernanda Brandão Mollica ${ }^{a}$ \\ Carolina Ferraz Ribeiro a \\ Maria Amélia Máximo de Araujo “ \\ Rebeca Di Nicolób \\ Ivan Balducci ${ }^{\circ}$
}

\begin{abstract}
- Department of Restorative Dentistry, São José dos Campos School of Dentistry, São Paulo State University (UNESP), São José dos Campos, SP, Brazil

b Department of Social Dentistry and Infantile Clinic, São José dos Campos School of Dentistry, São Paulo State University (UNESP), São José dos Campos, SP, Brazil
\end{abstract}

Correspondence:

Fernanda Brandão Mollica

Rua José Ferreira, 92, Jd Aquarius

São José dos Campos, SP - Brazil

12246-004

E-mail: femollica@gmail.com 


\section{Introduction}

The anti-cariogenic activity of fluoride has essential importance for controlling various diseases. Several mechanisms are involved in the anti-cariogenic effect, including demineralization reduction, remineralization stimulation, interference with the formation of the acquired pellicle and dental biofilm, and the inhibition of bacterial growth and metabolism. Bacterial adhesion mainly occurs in rough areas of both natural (enamel and cementum) and restorative materials (1). Therefore, restorative materials should prevent recurrent caries by minimizing both bacterial-site formation and colonization of the restorative material/tooth interface (2).

Fluoride-containing restorative materials are able to release a specific amount of fluoride, providing an anti-cariogenic effect. Conventional and resin-modified glass-ionomer and some composite resins are capable of fluoride release. Fluoride released by glass-ionomer cements is strongly dependant on the cement composition. The amount of fluoride released by glass-ionomer cement is more evident in the first 24 hours (3) and gradually decreases until it stabilizes after 10 to 20 days (4). Interestingly, glass-ionomer cements are capable of fluoride uptake when the patient is exposed to fluoride water and dentifrices, fluoride solutions for mouth rinsing, and topical fluoride applications. Therefore, glassionomer cements become a reservoir of fluoride.

Topical fluoride application performed immediately after the restoration also contributes to fluoride uptake by the restorative material (5). Besides that, the ability of a restoration to act as a fluoride reservoir is mainly dependent on the material permeability, frequency of exposure to fluoride, and the type and concentration of the fluoride agent (6). The high reactivity of fluoride agents used in topical applications cause concern regarding the adverse effects on restorative materials (7). Acidulated phosphate fluoride creates superficial erosion on the outmost surface of composite resin $(8,9)$ and glass-ionomer cement $(10,11)$.

Acidulated phosphate fluoride gel (1.23\%) seems to be most effective at increasing fluoride release by restorative materials, compared to $1 \%$ neutral fluoride gel, $0.001 \%$ calcium fluoride, and $4 \%$ stannous fluoride $(5,12,13)$. However, because of its deleterious effects on the surface roughness of restorative materials, the topical application of acidulated phosphate fluoride gel remains controversial $(10,11)$.

The aim of this study was to evaluate the topical application of acidulated phosphate fluoride on surface roughness of both dental enamel and different restorative materials. The null hypothesis tested was that the surface roughness of both the enamel and different restorative materials would not be influenced by topical application of acidulated phosphate fluoride.

\section{Methods}

Ten intact human third molars were selected after the approval of the Ethical Committee of São José dos
Campos School of Dentistry, UNESP, São José dos Campos, SP, Brazil. Teeth were cleaned with a periodontal curette and polished with pumice stone and water using a Robinson brush mounted in a contra-angle hand piece. All teeth were kept in distilled water at $-4^{\circ} \mathrm{C}$, which was periodically changed, for a period of six months (ISO 11405).

The selected teeth were sectioned with a precision low-speed diamond saw (Labcut 1010, Extec, São Paulo, SP, Brazil) in the mesio-distal direction and at the enamel-cement junction to obtain two halves, one buccal and one lingual half. From each half, a $5 \times 5 \mathrm{~mm}$ enamel specimen was obtained and used as the control (Fig. 1).

The same operator prepared sixty restorative material specimens in a stainless steel bipartite matrix with an orifice of $5 \mathrm{~mm}$ in diameter and $2 \mathrm{~mm}$ in thickness. The composite resins were inserted into the matrix using a composite placement instrument followed by the application of an artist's sable brush. A Centrix syringe was used for inserting the glass ionomer cement. A 10-mm-wide Mylar matrix strip (K-Dent - Quimidrol, Com. Ind. Importation Ltd, Joinville, SC, Brazil) followed by a flat glass slab were used to cover the specimens. The polymerization tip was applied directly against the glass slab, and the specimen was light-cured with a halogen light (Curing Light XL 3000, 3M ESPE, Dental Products, Saint Paul, MN, USA) according to each manufacturer's instructions. The light output was constantly monitored by a light intensity radiometer with an average of $600 \mathrm{~mW} / \mathrm{cm}^{2}$.

The polishing procedure was accomplished manually with 1200 -grit sandpaper for $40 \mathrm{~s}$. The specimens were randomly assigned into six experimental groups $(n=10)$ according to the restorative material used and the topical fluoride application (Fig. 1).

The VF, TF, ZF, and EF groups were superficially treated with $1.23 \%$ acidulated phosphate fluoride (DFL, Rio de Janeiro, RJ, Brazil), pH 5, which was composed of sodium fluoride, cellulose, fluoridric acid, phosphoric acid, propylenoglicol, colorant, flavor, and deionized water. APF (1.23\%) was applied for 4 min $(14,15)$ immediately after the specimen preparation and again after a 24-hour period to simulate fluoride application twice a year (16). The fluoride excess was removed by a suction canula, and the specimens were kept in $5 \mathrm{~mL}$ of artificial saliva, $\mathrm{pH} 7$ (Fig. 2), at $37^{\circ} \mathrm{C}$ for 7 days $(14,17)$. After this period, specimens were washed with $200 \mathrm{~mL}$ of distilled water for $10 \mathrm{~min}$ (15).

The groups V, T, Z, and E that did not receive APF application were kept in artificial saliva for seven days until the surface roughness analysis.

The mean surface roughness (Ra) was assessed by a profilometer (Mitutoyo SJ 400, Tokyo, Japan) at the micrometric scale $(\mu \mathrm{m})$ to obtain the arithmetic mean of the absolute values of the ordinate distances (peaks and valleys) of the medium line inside the measurement path. Each specimen's surface was placed parallel to the horizontal plane and perpendicular to the tip of the profilometer that measured the surface roughness of the specimen along a 3-mm path. 


\begin{tabular}{|c|c|c|c|c|c|}
\hline Group & Fluoride application & Restorative material & Commercial brand & Manufacturer & Composition \\
\hline V & no & \multirow{3}{*}{$\begin{array}{l}\text { Resin-modified glass } \\
\text { ionomer cement }\end{array}$} & \multirow{3}{*}{ Vitremer } & \multirow{3}{*}{$\begin{array}{l}\text { 3M ESPE, St. } \\
\text { Paul, MN, USA }\end{array}$} & \multirow{3}{*}{$\begin{array}{l}\text { Powder: fluoraluminosilicate glass, persulfate of } \\
\text { potassium and ascorbic acid } \\
\text { Liquid: aqueous solution of copolymers of } \\
\text { polialcenoic acid, HEMA e camphoroquinone } \\
\text { Primer: copolymers of polialcenoic acid, HEMA, } \\
\text { ethanol e photoinitiators } \\
\text { Glazer: Bis-GMA, TEGDMA e camphoroquinone. }\end{array}$} \\
\hline & & & & & \\
\hline VF & yes & & & & \\
\hline $\mathrm{T}$ & no & \multirow{2}{*}{$\begin{array}{l}\text { Microhybrid composite } \\
\text { resin with fluoride }\end{array}$} & \multirow{2}{*}{ Tetric Ceram } & \multirow{2}{*}{$\begin{array}{l}\text { Ivoclar Vivadent, } \\
\text { Schaan, } \\
\text { Liechtenstein }\end{array}$} & \multirow{2}{*}{$\begin{array}{l}\text { Bis-GMA, UDMA and TEGDMA. } \\
\text { Particles of } 700 \mathrm{~nm} \text { of silica and aluminum barium } \\
\text { fluorosilicate }\end{array}$} \\
\hline $\mathrm{TF}$ & yes & & & & \\
\hline Z & no & \multirow{2}{*}{$\begin{array}{l}\text { Nanofiller composite } \\
\text { resin without fluoride }\end{array}$} & \multirow{2}{*}{ Z350 } & \multirow{2}{*}{$\begin{array}{l}\text { 3M ESPE, St. } \\
\text { Paul, MN, USA }\end{array}$} & \multirow{2}{*}{$\begin{array}{l}\text { Bis-GMA, Bis-EMA, UDMA and TEGDMA. } \\
\text { Particles of silica of } 20 \mathrm{~nm} \text { and nanoclusters of } \\
\text { zircon/silica from } 600 \text { to } 1400 \mathrm{~nm} \text {. }\end{array}$} \\
\hline $\mathrm{ZF}$ & yes & & & & \\
\hline$E$ & no & \multirow{2}{*}{ Human dental enamel } & & & \\
\hline $\mathrm{EF}$ & yes & & & & \\
\hline
\end{tabular}

Fig. 1. Characteristics of the experimental and control groups.

\begin{tabular}{|l|c|}
\hline \multicolumn{1}{|c|}{ Composition } & Amount in $1000 \mathrm{~g}$ \\
\hline Potassium chloride & $0.96 \mathrm{~g}$ \\
\hline Sodium chloride & $0.67 \mathrm{~g}$ \\
\hline Magnesium chloride & $0.04 \mathrm{~g}$ \\
\hline Potassium phosphate & $0.27 \mathrm{~g}$ \\
\hline Calcium chloride & $0.12 \mathrm{~g}$ \\
\hline Nipagin & $0.01 \mathrm{~g}$ \\
\hline Nipasol & $0.1 \mathrm{~g}$ \\
\hline Carboxi Methyl Cellulose & $8.0 \mathrm{~g}$ \\
\hline Sorbitol & $24.0 \mathrm{~g}$ \\
\hline Water & $1000 \mathrm{~mL}$ \\
\hline
\end{tabular}

Fig. 2. Artificial saliva composition.

Two areas in the center of each specimen were selected for analyzing the surface roughness, with a 1-mm distance between them. In each area, two measurements perpendicular to each other were performed, for a total of four measurements of surface roughness per specimen.

The data were analyzed with two-way ANOVA, Tukey's, Student's t-, and Dunn-Bonferroni tests, at the 5\% significance level. The Student's t-test was used for comparing the surface roughness of the enamel with and without fluoride. The Dunn-Bonferroni test evaluated the roughness-value distributions of the three restorative materials (Vitremer, Tetric Ceram, and Z350) in comparison to the enamel with and without fluoride. Descriptive (mean, standard deviation, and coefficient of variation) and inferential statistics were analyzed by a two-way analysis of variance and Tukey's multiple comparison tests to evaluate the relationship between fluoride and restorative materials.

\section{Results}

The two-way ANOVA and Tukey's test for identifying homogenous groups are presented in Tables 2 and 3, respectively. The EF group $(21.19 \pm 4.42 \mu \mathrm{m})$ showed roughness values significantly higher than group $\mathrm{E}$ $(16.99 \pm 3.59 \mu \mathrm{m})(\mathrm{t}-$ Student $=2.33 ; \mathrm{df}=17 ; P=0.033)$.
The E group $(16.99 \mu \mathrm{m})$ statistically differed from the $\mathrm{V}(2.70 \mu \mathrm{m}), \mathrm{T}(2.10 \mu \mathrm{m})$, and $\mathrm{Z}(0.60 \mu \mathrm{m})$ groups, showing significantly higher mean roughness values by the DunnBonferroni test (Table 1 and Fig. 3). In the same way, the EF group $(21.19 \mu \mathrm{m})$ presented mean roughness values significantly higher than the VF $(1.18 \mu \mathrm{m})$, TF $(1.00 \mu \mathrm{m})$, and $\mathrm{ZF}(1.05 \mu \mathrm{m})$ groups.

Table 1. Dunn-Bonferroni's test (5\%) for comparison of the surface roughness of three restorative materials against enamel (control).

\begin{tabular}{clccc}
\hline Condition & Material & Calculated Z & $Z_{\text {critical(5\%) }}$ & $P$-value \\
\hline Without fluoride & Z350 & 5.738 & & 0.00010 \\
& Tetric Ceram & 3.118 & 2.3939 & 0.00018 \\
& Vitremer & 2.620 & & 0.00880 \\
With fluoride & Z350 & 3.730 & & 0.00020 \\
& Tetric Ceram & 4.523 & 2.3939 & 0.00130 \\
& Vitremer & 3.223 & & 0.00010 \\
\hline
\end{tabular}
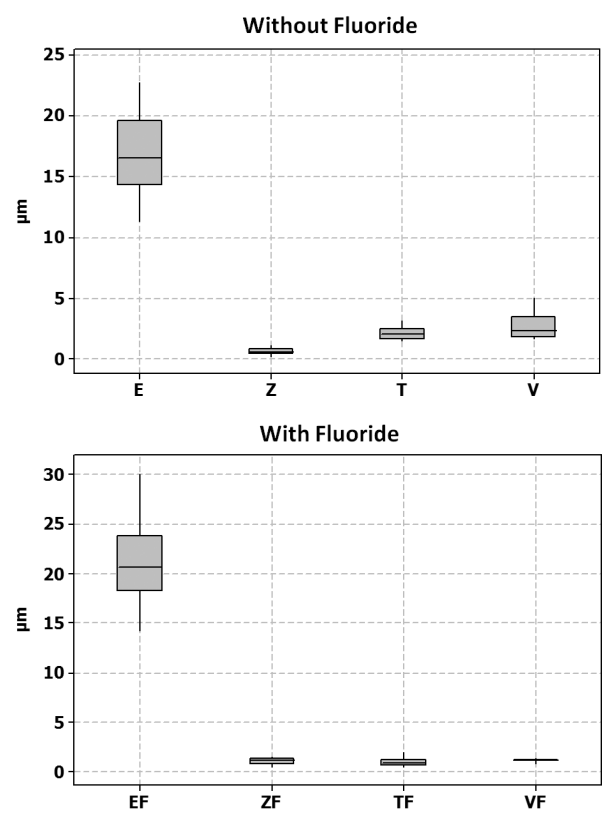

Fig. 3. Box-plot of mean surface roughness $(\mu \mathrm{m})$ of the experimental groups. 
Table 2. Output of two-way ANOVA for roughness data $(\mu \mathrm{m})$, after logarithmic transformation.

Table 3. Comparison of surface roughness among the experimental groups.

\begin{tabular}{lccccc}
\hline \multicolumn{1}{c}{ Effect } & $\begin{array}{c}\text { Degrees of } \\
\text { freedom }\end{array}$ & Squares Sum & Mean Square & F Ratio & P \\
\hline Material & 2 & 1.48093 & 0.74047 & 30.51 & $0.0001^{*}$ \\
Fluoride & 1 & 0.26964 & 0.26964 & 11.11 & $0.0001^{*}$ \\
Interaction & 2 & 1.21330 & 0.60665 & 25.00 & $0.0001^{*}$ \\
Residue & 54 & 1.31056 & 0.02427 & & \\
Total & 59 & 4.27443 & & & \\
\hline
\end{tabular}

\begin{tabular}{cccc}
\hline Groups & Ra $(\mu \mathrm{m}) \pm s d ;(\mathrm{cv} \%)$ & Log (mean) & Homogenous Groups* \\
\hline V & $2.70 \pm 1.12 ; 41.29$ & 0.4022 & $\mathrm{~A}$ \\
VF & $1.18 \pm 0.17 ; 14.12$ & 0.0706 & $\mathrm{~B}$ \\
T & $2.10 \pm 0.50 ; 23.62$ & 0.3122 & $\mathrm{~A}$ \\
TF & $1.00 \pm 0.40 ; 39.72$ & -0.0266 & $\mathrm{~B}$ \\
Z & $0.60 \pm 0.26 ; 43.95$ & -0.2670 & $\mathrm{~B}$ \\
ZF & $1.05 \pm 0.33 ; 31.40$ & 0.0004 & $\mathrm{~B}$ \\
\hline
\end{tabular}

* Tukey's multiple comparison test (5\% level of significance).

\section{Discussion}

Although some authors have suggested that topical application of APF could restore the fluoride levels of glassionomer cements (18), both hydrofluoridric and phosphoric acids, which are present in acidulated phosphate fluoride, could cause superficial structural damage to these materials (19). In addition, the $\mathrm{pH}$ of acidulated phosphate fluoride is approximately 5.0, which can cause erosion of the cement due to the acid etching of the surface (20).

The mean critical value of surface roughness for bacterial colonization of several dental materials has been measured as $0.2 \mu \mathrm{m}(21)$. Above this value, increased bacterial colonization, dental plaque, and acid formation are expected, which could damage the restorative material surface (10). In the present study, all mean surface roughness values were above this critical value. The surface roughness values of human enamel for both the E $(16.99 \mu \mathrm{m})$ and $\mathrm{EF}(21.19 \mu \mathrm{m})$ groups were higher than those found for the different restorative materials tested. This could be explained by the absence of surface polishing of the enamel specimens, which were kept intact and therefore maintained their inherent roughness (22).

According to Yap and Mok (23), the composition of the filler particles of composite resin could influence the effect of acidulated phosphate fluoride on a surface. Composite resins containing barium boro aluminum silicate are more susceptible to the effect of this fluoride. The use of fluoride topical applications could deteriorate, in the long term, the restorative material durability (23). The composition of restorative materials determines the surface roughness. The differences in compositions explain the range of roughness between the two composite resins used. Tetric Ceram generally showed higher Ra values than Z350. The Tetric Ceram particle size is about $700 \mathrm{~nm}$, whereas Z350 nanoparticles are $20 \mathrm{~nm}$ on average.

In the present study, fluoride topical application was capable of increasing the surface roughness only of human enamel. When fluoride was applied on microhybrid composite resin
(Tetric Ceram) and resin-modified glass-ionomer cement (Vitremer), fluoride was found to decrease the surface roughness. These results would suggest that APF might have chemically attacked the inorganic particles of Vitremer and Tetric. This seemed to contribute to the surface smoothing because, in the group with nanometer-sized particles (Z350), APF application did not cause surface alteration.

Acidulated phosphate fluoride did not promote a modification of the surface roughness of the nanofiller composite resin. Our findings are in agreement with Soeno et al. (9), who observed that the influence of APF application on the material's surface roughness decreased as the size of the filler particles of the composite resin decreased. The explanation for this fact is that APF can attack the inorganic particles, and when these are very small, as in the nanofiller composite resins, the size of the defects created by APF are practically imperceptible. Yip and Smales (18) observed that a $1.23 \%$ APF application for four minutes increased the surface roughness of conventional glass-ionomer cements. However, Pedrini et al. (24) did not find alterations in surface roughness of resin-modified glass ionomer after applying 1.23\% APF for one minute.

It is important to highlight that the dentist should be cautious when applying APF on dental enamel and composite resins restorations with macroparticles to prevent the acid etching of inorganic particles (9) and increased surface roughness. However, the topical application of APF for four minutes is recommended on microhybrid and nanofiller composite resins and resin-modified glass-ionomer cements because it does not promote increased surface roughness.

\section{Conclusions}

- APF increased the surface roughness of enamel.

- Topical APF application decreased the surface roughness of both resin-modified glass-ionomer cement and microhybrid composite resin with fluoride.

- The surface roughness of nanofiller composite resin was not modified by APF. 


\section{Acknowledgments}

The authors would like to thank the Department of Restorative Dentistry of São José dos Campos School of Dentistry (UNESP) for its support of this study and Dr. Sillas Duarte Júnior for editorial assistance.

\section{References}

1. Tanner J, Robinson C, Söderling E, Vallittu P. Early plaque formation on fibre-reinforced composites in vivo. Clin Oral Investig 2005;9:154-60.

2. Gonzalez-Cabezas C, Li Y, Gregory RL, Stookey GK. Distribution of three cariogenic bacteria in secondary carious lesions around amalgam restorations. Caries Res 1999;33:357-65.

3. Wiegand A, Buchalla W, Attin T. Review on fluoride-releasing restorative materials - fluoride release and uptake characteristics, antibacterial activity and influence on caries formation. Dent Mater 2007;23:343-62.

4. Vermeersch G, Leloup G, Vreven J. Fluoride release from glassionomer cements, compomers and resin composites. J Oral Rehabil $2001 ; 28: 26-32$.

5. Gao W, Smales RJ, Gale MS. Fluoride release/uptake from newer glass ionomer cements used with the ART approach. Am J Dent 2000; 13:201-4.

6. Han L, Cv E, Li M, Niwano K, Ab N, Okamoto A, et al. Effect of fluoride mouth rinse on fluoride releasing and recharging from aesthetic dental materials. Dent Mater J 2002;21:285-95.

7. Papagiannoulis L, Tzoutzas J, Eliades G. Effect of topical fluoride agents on the morphologic characteristics and composition of resin composite restorative materials. J Prosthet Dent 1997;77: 405-13.

8. Turssi $C P$, de Magalhães CS, Serra MC. Effect of fluoride gels on micromorphology of resin-modified glass-ionomer cements and polyacid-modified resin composites. Quintessence Int $2001 ; 32: 571-7$.

9. Soeno K, Matsumura H, Kawasaki K, Atsuta M. Influence of acidulated phosphate fluoride agents on surface characteristics of composite restorative materials. Am J Dent 2000;13:297. 300.

10. Yip KH, Peng D, Smales RJ. Effects of APF gel on the physical structure of compomers and glass ionomer cements. Oper Dent $2001 ; 26: 231-8$.

11. Dionysopoulos P, Gerasimou P, Tolidis K. The effect of home-use fluoride gels on glass-ionomer, compomer and composite resin restorations. J Oral Rehabil 2003;30:683-9.

12. Diaz-Arnold AM, Holmes DC, Wistrom DW, Swift Jr EJ. Short-term fluoride release/uptake of glass ionomer restoratives. Dent Mater 1995; 11:96-101.
13. Bilgin Z, Ozalp N. Fluoride release from three different types of glass ionomer cements after exposure to $\mathrm{NaF}$ solution and APF gel. Clin Pediatr Dent 1998;22:237-41.

14. Eronat C, Eronat N, Alpöz AR. Fluoride uptake by enamel in vitro following application of various topical fluoride preparations. J Clin Pediatr Dent 1993;17:227-30.

15. Benediktsson S, Retief DH, Bradley EL, Switzer P. The effect of contact time of acidulated phosphate fluoride on fluoride concentration in human enamel. Archs Oral Biol 1982;27:567-72.

16. Hawkins R, Locker D, Noble J, Kay EJ. Prevention. Part 7: professionally applied topical fluorides for caries prevention. $\mathrm{Br}$ Dent J 2003;195:313-7.

17. Retief DH, Bradley EL, Holbrook M, Switzer P. Enamel fluoride uptake, distribution and retention from topical fluoride agents. Caries Res 1983; 17:44-51.

18. Yip HK, Smales RJ. Fluoride release and uptake by aged resinmodified glass ionomers and a polyacid modified resin composite. Int Dent J 1999;49:217-25.

19. Kula K, Nelson S, Kula T, Thompson V. In vitro effect of acidulated phosphate fluoride gel on the surface of composites with different filler particles. J Prosthet Dent 1986;56:161-9.

20. Crisp $S$, Lewis BG, Wilson AD. Characterization of glass ionomer cements.6. A study of erosion and water absorption in both neutral and acidic media. J Dent 1980;8:68-74

21. Bollen CML, Lambrechts $P$, Quirynen M. Comparison of surface roughness of oral hard materials to the threshold surface roughness for bacterial retention: a review of the literature. Dent Mater 1997; 13:258-69.

22. Silva RCSP. Avaliação da rugosidade superficial de restaurações estéticas e do esmalte adjacente após o uso de diferentes instrumentos rotatórios de acabamento e polimento [tese]. São José dos Campos (SP): Faculdade de Odontologia, Universidade Estadual Paulista; 1997.

23. Yap AU, Mok BY. Effects of professionally applied topical fluorides on surface hardness of composite-based restoratives. Oper Dent 2002;27:576-81.

24. Pedrini D, Gaetti-Jardim Jr E, Mori GG. Influência da aplicação de flúor sobre a rugosidade superficial do ionômero de vidro Vitremer e adesão microbiana a este material. Pesqui Odontol Bras $2001 ; 15: 70-6$. 